\title{
ANTIMICROBIAL RESISTANCE OF ESCHERICHIA COLI STRAINS ISOLATED FROM PATIENTS WITH PURULENT PERITONITIS
}

\author{
Kharkiv National Medical University
}

\begin{abstract}
Escherichia coli remains one of the most frequent causes of several common bacterial infections in humans. Surgery on the abdominal cavity is usually complicated by peritonitis caused by E. coli strains. Recently, there are data confirming the high degree of resistance of this strain. The prevalence of multidrug-resistant E. coli strains is increasing worldwide principally due to the spread of mobile genetic elements, such as plasmids. The rise of multidrug-resistant strains of E. coli also occurs in Ukraine. Therefore, the spread of resistance E. coli is an increasing public health concern in our country. This paper summarizes the antibiotic resistance of clinical E. coli strains, isolated from patients with peritonitis. Furthermore, therapeutic interventions and strategies to prevent and control infections are presented and discussed. The article also provides an overview of the current knowledge concerning promising alternative therapies against E. coli diseases.
\end{abstract}

Key words: antibiotic resistance; E. coli strains; purulent peritonitis.

"... I and my contemporaries were brought up in fear of God and inflammation of the abdominal cavity ..." - these are words of the famous German surgeon of the last century Wegner (1876). He studied the scientific problem of purulent peritonitis, which made it possible to fully reflect the complexity of the clinical situation that arose when a surgeon had collided with peritonitis [1].

Peritonitis is an infectious and inflammatory process of the abdominal cavity with damage to the visceral and parietal peritoneum and bordering tissues. Despite the fact that today many issues of pathogenesis, diagnosis, surgical treatment and intensive postoperative therapy of the infectious process in the abdominal cavity have been largely studied, the mortality rate among this category of patients remains high and reaches $40-90 \%$. The causes of acute purulent peritonitis (PP) are extremely diverse. Most often it is a consequence of gangrenous perforated appendicitis (40\%), perforation of the intestine affected by the tumor, nonspecific ulcerative process ( $25 \%$ ). According to V. V.
Moskalenko et al., peritonitis is an autoinfectious polymicrobial disease [2]. Along with adequate surgical intervention, antibiotic therapy occupies one of the leading places in the treatment of peritonitis. At the same time, the stereotyped choice of drugs, without taking into account the antibiotic resistance of the isolated strains only worsens the course of the disease and increases the lethality. It is known that sanitation of the abdominal cavity is one of the key components of its surgical treatment. However, the effectiveness of washing the peritoneum is due to a purely mechanical washout of microorganisms with using of various antibiotics and antiseptics can lead to increase in the number of strains resistant to them. At the same time, the qualitative and quantitative composition of the microflora has an important prognostic value. Until recently, the infectious process of the abdominal cavity was mistakenly presented as a monoinfection, mainly caused by Escherichia coli or Staphylococci, less often by their associations. Bacteriological studies of recent years have shown the polymicrobial nature of the developing infection with the participation of a variety of aerobic and anaerobic microorganisms. Also in the mechanism of general pathophysiological reactions in purulent peritonitis, the main role is assigned to intoxication. The leading factor of the development of toxicosis belongs to Escherichiosis toxin. It enters the general bloodstream from the infected abdominal cavity. In turn, the developing intestinal paresis leads to indigestion, fermentation, rotting of intestinal contents and the absorption of toxic products of protein hydrolysis. The formation of a significantly exceeding physiological amount of biologically active substances not only has a toxic effect, but also it affects the microcirculation system, tissue metabolism. It should be noted that the effectiveness of antibiotic therapy depends, on the one hand, on the sensitivity of the pathogens of the infectious process to the antimicrobial drugs used, and on the other, on the permeability of the drugs to the inflammation focus and the place of vegetation of microorganisms. The solution of the second problem presents well-known difficulties. The 
presence of a heavily permeable highly contaminated fibrinous-purulent film and infected blood clots for antibiotics and antiseptics. Meanwhile, protein substrates serve as an optimal nutrient medium for growing microorganisms. The mechanical removal of fibrin layers leads to significant trauma to the deep structures of the visceral peritoneum and creates a prerequisite for the formation of adhesions, intestinal fistulas, and also promotes the penetration of microorganisms into the underlying tissues with the development of an inflammatory process in them [3]. It requires developing new methods of sanitation of the abdominal cavity and using of new groups of antibiotics. Before receiving a microbiological analysis of the antibiotic sensitivity of microflora. As a rule, there are antibiotics of a wide spectrum of action (starting, empiric $A B T$ ) are prescribed, such as meropenems, fluoroquinolones of the III-IV generation, semisynthetic penicillins, cephalosporins of the III-IV generation, aminoglycosides and an antianaerobic agent [4]. One of the most actual problem in medicine is increasing of the resistance of microorganisms to antibacterial drugs. It should be noted that in recent years more than 1000 antibiotics have been discovered, but about 45 are used in clinical practice, which complicates the work of clinical doctors. The goal of modern scientists is to find ways which prevent the growth of antibiotic resistant strains. All of the above was the basic for this investigation.

Based on this, the goal of our experiment was to determine the antibiotic resistance of Escherihia coli strains isolated from surgical patients with purulent peritonitis.

\section{Materials and methods}

Microbiological data were obtained from patients of the surgical department of the Kharkiv City Emergency Hospital. (This work is part of the dissertation work). To achieve this goal, 136 patients with purulent peritonitis were examined. The material for the investigation was clinical strains of Escherihia coli isolated from the abdominal cavity. The work used microbiological methods for the isolation and identification of microorganisms, according with the current regulatory documents of the Ministry of Health of Ukraine. Clinical strains of Escherichia coli were identified going with the recommendations "Determination of Burgey bacteria" by cultural and biochemical properties (ENTERO test 16, Lachema, Czech Republic).

The sensitivity of strains Escherihia coli strains to chemotherapeutic drugs was studied on Mueller-Hinton agar (HiMedia) to the following antibiotics: ampicillin, doxycycline, lincomycin, amikacin, gentamicin, ciprofloxacin, norfloxacin, ceftriaxone, cefepim and meropenem (St. Petersburg, Russia).

For statistical processing of the results, the standard package of applied programs Biostat-4 and Microsoft Excel 2000 were used [5].

\section{Results and discussion}

As a result of the conducted microbiological studies, 141 different strains were isolated and identified. Microorganisms that belong to the family Enterobacteriacae and Microcococaccae were isolated in almost equal amounts (49.2\% and $50.8 \%$, respectively). It was found that Escherihia coli was the etiological factor of purulent peritonitis in $29.5 \%$ of cases. The sensitivity of Escherihia coli strains was determined using the disk diffusion method (DDM). We used antibiotics of various groups, which have of the greatest practical importance for the treatment of purulent peritonitis. Data on antibiotic resistance of Escherihia coli are presented in Table 1.

Table 1

Antimicrobial resistance of strains Escherihia coli

\begin{tabular}{|c|c|c|}
\hline \multirow{2}{*}{ Antibiotic } & \multicolumn{2}{|c|}{ Escherihia coli, $(n=36)$} \\
\hline & abs. & $(M \pm m) \%$ \\
\hline ampicillin & 14 & $38.9 \pm 8.1$ \\
\hline doxycycline & 12 & $33.3 \pm 7.8$ \\
\hline lincomycin & 4 & $11.1 \pm 5.2$ \\
\hline amikacin & 8 & $22.2 \pm 6.9$ \\
\hline gentamicin & 6 & $16.7 \pm 6.2$ \\
\hline ciprofloxacin & 4 & $11.1 \pm 5.2$ \\
\hline norfloxacin & 5 & $13.9 \pm 5.8$ \\
\hline ceftriaxone & 4 & $11.1 \pm 5.2$ \\
\hline cefepim & 4 & $11.1 \pm 5.2$ \\
\hline meropenem & 12 & $33.3 \pm 7.8$ \\
\hline
\end{tabular}

As can be seen from the data in Table 1 the most resistant strains of Escherihia coli were to ampicillin and doxycycline (38.9 $\pm 8.1-33.3 \pm 7.8 \%$, accordingly). Similar results were obtained when determining the antibiotic sensitivity of $E$. coli to meropenem $(33.3 \pm 7.8) \%$. It should be noted that resistance of this microorganism to aminoglycosides was approximately at the same level (to gentamicin $-16.7 \pm 6.2$ and amikacin $-22.2 \pm 6.9 \%$ ). Analysis of the obtained results showed the most active antibiotics against $E$. coli were ciprofloxacin, norfloxacin, ceftriaxone, cefepime, and lincomycin. The number of resistant strains to them ranged from $(11.1 \pm 5.2)$ to $(13.9 \pm 5.8) \%$.

It was found that among the isolated strains of $E$. coli $19.4 \%$ of the strains were multidrug resistant. This process is going to the natural biological response of the microorganism as a result of the using of antibiotics. Antibacterial drugs have a selective effect that promotes the selection, survival and reproduction of resistant bacteria. 
Today ß-lactam antibiotics are the basis of therapy for most infections. Unfortunately, resistance to this group of antibiotics is growing every day. Such a rapid spread of such strains is due to the transmission of genetic determinants of resistance. On the other hand, the resistance of strains to this group of antibiotics is due to the production of $\beta$-lactamases. These enzymes are capable of hydrolyzing natural, semi-synthetic and synthetic penicillins [6].

Antibiotic resistance to carbapenems is explained by the breaking of the structure of the porin channels of microorganisms, the active elimination of antibiotics from the microorganism, as well as inactivation by the enzyme - carbapenemase [7].

The mechanism of action aminoglycosides is associated with irreversible inhibition of protein synthesis at the level of ribosomes in microorganisms sensitive to them. Aminoglycosides of the $2^{\text {nd }}$ and $3^{\text {rd }}$ generations have a wide spectrum of antimicrobial activity. They are primarily used against most gram-negative microorganisms of the Enterobacteriaceae family. Resistance to aminoglycosides in microorganisms is due to their ability to produce specific enzymes (aminoglycoside acetyltransferase, N-phosphate transferase, O-nucleotidyltransferase) that inactivate these antibiotics. The gentamicin-resistant strains in most cases are also resistant to $1^{\text {st }}$ generation drugs (streptomycin, neomycin, kanamycin, and monomycin). The using of these drugs is limited due to their high toxicity. Representatives of the 3rd generation are active against gentamicin-resistant microorganisms. They include amikacin. It have to remember that aminoglycosides have a selective neuro- and nephrotoxic effect, which requires a clear justification of the indications for their appointment and careful monitoring of their concentration in the blood, renal function and taking an audiogram at least once a week. Aminoglycosides are rarely used as monotherapy and are usually given along with broad-spectrum $\beta$-lactams for severe infections with strains of gram-negative bacteria. However, with resistance to aminoglycosides, fluoroquinolones are prescribed at the initial stages of empirical treatment [8].

Nowadays fluoroquinolones (FQ), due to their significant role in the therapy of infectious processes, are rightfully in the forefront of the "fighters against microbes". The mechanism of action of FQ is the inhibition of DNA gyrase, leading to blocking of DNA replication and the synthesis of their own proteins by microorganisms, which provides a rapid bactericidal effect. Resistance to $\mathrm{FQ}$ is very rare, only due to chromosomal mutations in bacteria. Enzymatic inactivation of these drugs by bacteria and resistance caused by plasmids are also often observed. For FQs, cross-reactions with other classes of antibacterial agents are not typical. Quinolone resistance may result from gene expression of the efflux system. This is one of the main mechanisms of quinolone resistance. For the time being this group of antibiotics has no analogues in the natural environment, which provides them with high activity in relation to multi-resistant strains of microorganisms [9].

\section{Conclusions}

1. The antibiotic susceptibility of the isolated $E$. coli strains from patients with PP showed that they were

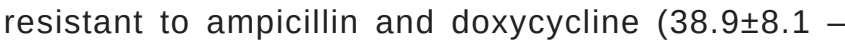
$33.3 \pm 7.8) \%$. Similar data were obtained when the antibiotic sensitivity of $E$. coli was determined to meropenem (33.3 \pm 7.8$) \%$.

2. The results of microbiological examination showed that $E$. coli strains retained their resistance to aminoglycosides at the same level (to gentamicin $-16.7 \pm 6.2$ and amikacin $-22.2 \pm 6.9 \%)$.

3. The most effective antibiotic against $E$. coli were ciprofloxacin, norfloxacin, ceftriaxone, cefepime, and lincomycin. The number of resistant strains to them was more less $11.1-13.9 \%$.

4. It was found that $19.4 \%$ of $E$. coli strains had multidrug resistance to antibacterial drugs.

Thus, antibiotics of the fluoroquinolone series and cephalosporins of the 2-3 generation had the highest activity relative to $E$. coli strains isolated from patients with purulent peritonitis. The obtained data correspond with the results of the work of other scientific researchers who studied the antibiotic resistance of $E$. coli strains $[10,11]$

\section{Perspective of researching}

The spread of resistant $E$. coli strains indicates a significant decrease in the effectiveness of antibacterial drugs of various groups. Particular attention is drawn to the specific gravity of multiresistant microorganisms. The antibiotics such as ciprofloxacin, ceftriaxone, cefepime and lincomycin were most active against $E$. coli. These medicines may be considered the drugs of choice for empiric treatment until the antibiotic susceptibility of microorganisms will be determined. The variability of resistant strains to antibacterial drugs and the appearance of dangerous genes for antibiotic resistance confirm the need to monitor antibiotic resistance of $E$. coli strains that cause the development of purulent peritonitis. 


\section{ОРИГІНАЛЬНІ ДОСЛІДЖЕННЯ}

\section{List of literature}

1. Возможности эндовидеохирургических вмешательств в лечении перитонита (обзор литературы) / Е.А. Ярцева, А.И. Шугаев, А.Л. Луговой и др..// Вестник СПбГУ. - 2014. - № 11(2). - С. 93-102.

2. Показатели клеточного и гуморального иммунитета у больных перитонитом, вызванным заболеваниями и травмами верхних мочевыводящих путей / В.А. Мусаилов, О.Э. Луцевич, П.Е. Крайнюков и др. // Московский хирургический журнал. - 2018. - №4(62) - C. 39-44.

3. Воронков Д.Е. Диагностика и лечение распространенного перитонита. - Дисс. ... канд.. мед наук. - Краснодар, 2018.

4. Wiest R. Spontaneous bacterial peritonitis: recent guidelines and beyond / R. Wiest, A. Krag, A. Gerbes // Gut. - 2012. - N 61. P. 297-310.

5. Наказ МОЗ України № 167 від 05.04.07. Про затвердження методичних вказівок «Визначення чутливості мікроорганізмів до антибактеріальних препаратів». - К., 2007. - 52 с.

6. Yoneyama $\mathrm{H}$. Antibiotic Resistance in Bacteria and Its Future for Novel Antibiotic Development / H. Yoneyama, R. Katsumata //

\section{References}

1. Yartseva, E.A., Shugaev, A.I., Lugovoy, A.L., Zemlianoy, V.P., \& Grebcov, Yu.V. (2014). Possibilities of endovideosurgical interventions in the treatment of peritonitis (literature review). Bulletin of St. Petersburg State University, 11(2), 93-102 [in Russian].

2. Musailov, V.A., Lucevich, O.Ye., Krayniukov, P.E., Esipov, A.V., \& Shishlo, V.K. (2018). Parameters of cellular and humoral immunity in patients with peritonitis caused by diseases and injuries of the upper urinary tract. Moscow Surgical Journal, 4 (62), 39-44.

3. Voronkov, D.E. (2018). Diagnostic and treatment of advanced peritonitis. Extended abstract of candidate's thesis. Krasnodar [in Russian].

4. Wiest, R., Krag A., \& Gerbes, A. (2012). Spontaneous bacterial peritonitis: recent guidelines and beyond. Gut, 61, 297-310.

5. Order of the Ministry of Health of Ukraine No. 167 dated April 05, 2007. (2007). About the statement of methodical instructions "Determination of sensitivity of microorganisms to antibacterial drugs". Kyiv [in Ukrainian].
Bioscience, biotechnology and biochemistry. - Online ISSN: 13476947.

7. Andrew F. Read Antibiotic resistance management / F. Andrew, A. Read, R. Woods // Evol. Med. Public Health. - 2014. - Vol. 1. P. 147.

8. Degradation and transformation of fluoroquinolones by microorganisms with special emphasis on ciprofloxacin / M. Rusch, A Spielmeyer., H. Zorn, G. Hamscher // Applied Microbiology and Biotechnology. - 2019. - Vol. 103. - P. 6933-6948.

9. Escerichia coli: an old friend with new tidings / J. Vila, E. SáezLópez, J. R. Johnson [et al.] // FEMS Microbiology Reviews. - 2016. - Vol. 40, Issue 4. - P. 437-463.

10. Закиров Д.Б. Распространенный перитонит: проблемы и пути решения. - Дисс. ... доктора мед. наук. - Москва, 2007.

11. Мазурова О.И. Особенности диагностики и лечения послеоперационного перитонита. - Дисс. ... канд. мед. наук. - Москва, 2011.

6. Yoneyama, H., \& Katsumata R. (2013). Antibiotic resistance in bacteria and its future for novel antibiotic development. Bioscience, Biotechnology and Biochemistry, Online ISSN: 1347-694.

7. Read, A., \& Woods, R. (2014). Antibiotic resistance management. Evol. Med. Public Health, 1, 147.

8. Rusch, M., Spielmeyer, A., Zorn, H., \& Hamscher, G. (2019). Degradation and transformation of fluoroquinolones by microorganisms with special emphasis on ciprofloxacin. Applied Microbiology and Biotechnology, 103, P. 6933-6948.

9. Vila, J., Sáez-López, E., Johnson, J.R., Römling, U., Dobrindt, U., Cantón, R., Giske, C.G., Naas, T., Carattoli, A., \& Martínez-Medina, M. (2016). Escerichia coli: an old friend with new tidings. FEMS Microbiology Reviews, 40, 437-463.

10. Zakirov, D.B. (2007). Common peritonitis: problems of its solution. Extended abstract of Doctor's thesis [in Russian].

11. Mazurova, O.I. (2011). Features of diagnosis and treatment of postoperative peritonitis. Extended abstract of candidate's thesis. Moscow [in Russian] 


\section{АНТИМІКРОБНА РЕЗИСТЕНТНІСТЬ ШTAMIB ESCHERICHIA COLI, ВИДІЛЕНИХ ВІД ХВОРИХ НА ГНІЙНИЙ ПЕРИТОНІТ}

О.В. Коцар, О.В. Кочнєва

Харківський національний медичний університет

PЕЗЮME. Escherichia coli залишається однією $з$ найпоширеніших причин декількох бактерійних інфрекцій у людей. Операція, проведена на черевній порожнині, як правило, ускладнюється перитонітом, спричиненим итамами E. coli. Останнім часом з'являються дані, що підтверджують високий ступінь стійкості цього мікроорганізму до антибіотиків. Поширеність мультирезистентних итамів E. coli зростає у всьому світі, головним чином через поширення мобільних генетичних елементів, таких як плазміди. Також в Україні зростає кількість стійких до медикаментів штамів кишкової палички. Отже, поширення резистентності кишкової палички в нашій країні $є$ актуальною проблемою охорони здоров'я. У цій роботі узагальнено антибіотикорезистентність клінічних штамів E. coli, виділених від хворих на гнійний перитоніт. Крім того, представлені та обговорені терапевтичні втручання і стратегії запобігання й контролю інфрекцій. Наведено огляд сучасних знань про перспективні альтернативні методи лікування хвороб, зумовлених кишковою паличкою.

Ключові слова: антибіотикорезистентність, итами Escherichia coli, гнійний перитоніт.

\section{Відомості про авторів:}

Коцар Олена Василівна - к. мед. н., доцентка кафедри мікробіології, вірусології та імунології ім. Д.П. Гриньова Харківського медичного національного університету; e-mail: kotsar_76@ukr.net

ORCID ID: https://orcid.org/0000-0002-3797-1068

Кочнєва Олена Володимирівна - к. мед. н., старша викладачка кафредри мікробіології, вірусології та імунології ім. Д.П. Гриньова Харківського медичного національного університету; e-mail: elenakochneva@ukr.net

ORCID ID: https://orcid.org/0000-0002-1039-9913

Information about the authors:

Kotsar O.V. - PhD, Associate Professor of the Department of Microbiology, Virology and Immunology named after D. P. Hryniov, Kharkiv National Medical University; e-mail: kotsar76@ukr.net

ORCID ID: https://orcid.org/0000-0002-3797-1068

Kochnieva O.V. - PhD, senior teacher of the Department of Microbiology, Virology and Immunology named after D.P. Hryniov, Kharkiv National Medical University; e-mail: elenakochneva@ukr.net

ORCID ID: https://orcid.org/0000-0002-1039-9913.

Консрлікт інтересів: немає.

Authors have no conflict of interest to declare.

Отримано 2.03.2021 p. 